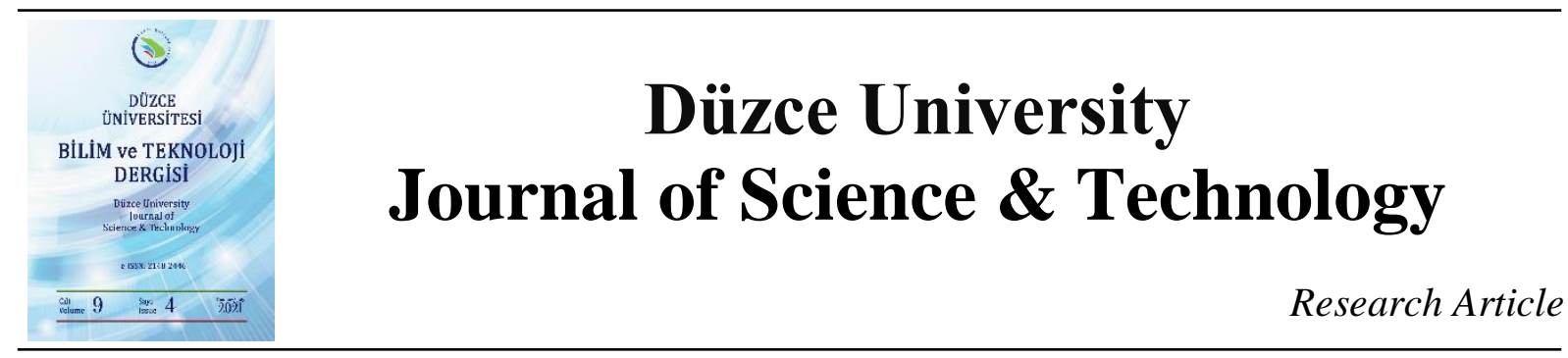

\title{
Optimization Packed Bed Column Reactor Parameters for Enzymatic Hydrolyzing of Lactose
}

\author{
Sevim Gürdaş MAZLUM ${ }^{\mathrm{a},{ }^{*},}$ (D) İsmail Hakkı BOYACI ${ }^{\mathrm{b}}$, (D) Mehmet MUTLU ${ }^{\mathrm{c}}$ \\ ${ }^{a}$ Department of Food Engineering, Faculty of Engineering, Cumhuriyet University, Sivas, TURKEY \\ ${ }^{b}$ Department of Food Engineering, Faculty of Engineering, Hacettepe University, Ankara, TURKEY \\ ${ }^{c}$ Department of Mechanical Engineering, Ostim Technical University, Ankara, TURKEY \\ * Corresponding author's e-mail address: sgurdas@cumhuriyet.edu.tr
}

DOI: $10.29130 /$ dubited.903157

\begin{abstract}
The purpose of the study to increase the conversion ratio of lactose hydrolysis to glucose and galactose via packed bed reactors containing immobilised enzyme and design a reactor that will achieve a high conversion ratio in continuous systems. For this purpose, the dynamic properties of a packed bed reactor containing immobilised $\beta$ galactosidase enzyme on Duolite A 568 resin were determined by a stimulus-response technique and moment analysis. The relation between kinetic behaviour and The dynamic response was determined via Peclet number $(\mathrm{Pe})$ and Damkohler number (Da). This study was completed with the development of a mathematical model using parameters such as flow dynamics, column geometry, enzyme immobilization performance and the behaviour of the enzyme in the column. According to the results, the particle size, L/D ratio and flow rate appropriate for this system were determined as $390 \mu \mathrm{m}, 10$ and $4 \mathrm{~mL} / \mathrm{min}$, respectively. Furthermore, 55\% conversion of lactose from milk was obtained using the enzyme immobilized packed bed reactor.
\end{abstract}

Keywords: Packed bed column, $\beta$-galactosidase, Stimulus-response technique, Moment analysis.

\section{Laktozun Enzimatik Hidrolizi için Dolgulu Kolon Reaktör Parametrelerinin Optimizasyonu}

\begin{abstract}
ÖZ
Çalışmanın amacı, enzim tutuklu dolgulu kolon reaktör ile laktoz hidrolizinin glikoz ve galaktoza dönüşüm oranını arttımak ve sürekli sistemde yüksek dönüşüm sağlayacak bir reaktör tasarlamaktır. Bu amaçla Duolite A 568 reçinesine tutuklu $\beta$-galaktosidaz enzimi içeren dolgulu kolon reaktörün dinamik davranışı moment analizi ve uyarı cevap tekniği ile belirlendi. Kinetik davranış ile dinamik tepki arasındaki ilişki Peclet sayısı $(\mathrm{Pe})$ ve Damkohler sayısı $(\mathrm{Da})$ ile belirlendi. Bu çalışma akış dinamiği, kolon geometrisi, enzim immobilizasyon performansı ve enzimin kolondaki davranışı gibi parametreler kullanılarak matematiksel bir modelin geliştirilmesi ile tamamlandı. Bu veriler doğrultusunda hazırlanan enzim tutuklu dolgulu kolon reaktör sisteminde kullanılmas1 uygun olan partikül büyüklügü, kolon L/D oranı ve akış hızı sırasıyla $390 \mu \mathrm{m}, 10$ ve $4 \mathrm{~mL} / \mathrm{dk}$ olarak belirlenmiştir. Ayrıca enzim tutuklu dolgulu kolon reaktör ile sütteki laktozdan 55 \% dönüşüm elde edilmiştir
\end{abstract}

Anahtar Kelimeler: Dolgulu Kolon, $\beta$-galactosidase, Uyarı Cevap Tekniği, Moment Analizi. 


\section{INTRODUCTION}

Lactose is a disaccharide found in milk, which is absorbed by the intestinal tract after conversion to its monosaccharide into glucose and galactose by lactase [1]. Enzymatic hydrolysis of lactose is one of the most important biotechnological processes, which is used to remedy the symptoms of lactose-intolerant individuals [2,3]. A deficiency of $\beta$-galactosidases in the gastrointestinal tract gives rise to problems like abdominal pain and diarrhea. This is known as lactose intolerance [4]. Hydrolyzing lactose makes it easier for people with lactose intolerance to consume milk and also improves product sweetness, increases product quality and processing efficiency in the dairy industry [5]. Recently, an enzymatic method has become an alternative technique to acid hydrolysis due to its many important advantages based on the quality of the final product. Soluble and immobilized $\beta$-galactosidases are both used for lactose hydrolysis in industrial applications [6,7]. There is a great need for an immobilized enzyme system enhancing stability, imparting reusability and reducing enzyme processes cost and viable in low lactose milk production. The use of immobilized enzyme eliminates the enzyme separation step from the main process, thus simplifying and enhancing the overall process yield [8].

Packed-bed reactors, which have the widest application area in biological processes and enzymatic hydrolysis processes, are practical and efficient. They show higher conversion efficiencies than those of continuously stirred tank reactors. Packed-bed reactors require that ideal plug flow conditions are met and that equal residence times are considered. Their popularity further originates from their effectiveness in terms of performance as well as more economically $[9,10]$.

Mathematical modelling of a chemical process that includes flow depends on the details of the flow pattern of its elements and the distribution of the residence times [11-14]. This distribution obeys statistical laws and can be determined as a test signal passing through the system.

Injecting an amount of a tracer into the feed stream as a step input, as an impulse is likely to trigger a test signal. The concentration of a tracer injected instantly is seen at the system outlet over a series of time intervals, and the data are plotted to create a C- diagram. Centred on an impulse stimulus is the residence time distribution [11]. This method is called a stimulus-response technique. Stimulus-response techniques are used in different engineering operations but this is the first time one has been applied to an enzymatic process.

The residence times for fluid elements are determined based on the principle of statistical moments and the density function of probability. The zero moment of a probability density function is unity. The average value of the ensemble is the first moment, provides a measure of the place of the "centre" of the distribution and the second one is the variance, giving a measure of the symmetry or skewedness of the distribution regarding the mean [11].

This study was performed to determine the reaction conditions (flow dynamics and reaction kinetics) necessary to achieve minimum cost and maximum conversion. Its intended to design a packed bed reactor that will achieve high conversion ratios in continuous systems for the production of low lactose milk. This study was completed with the development of a mathematical model using parameters such as flow dynamics, column geometry, the behaviour of the enzyme in the column and the performance of the column developed according to the optimized parameters and tested using a milk sample.

\section{A. MATHEMATICAL MODEL}

When an impulse type stimulation is given to a packed bed column reactor prepared with global catalytic particles, it is estimated that the dynamic behaviour of the column (that of the C-curve) or, in other words, the probability distribution function, fits the dispersion model. The Differential equation which defines the process in the packed bed column reactor is represented by equation 1 [15].

The equation for a packed column with radius $r$ is written as follows: 
$\varepsilon \frac{\delta C}{\delta t}=-U \frac{\delta C}{\delta X}+D_{L}\left[\frac{\delta^{2} C}{\delta X^{2}}\right]+\frac{D_{R}}{r}\left[\frac{\delta}{\delta r}\left[r \frac{\delta C}{\delta r}\right]\right]-\rho_{p} N_{A^{\prime}}$

The radial and axial dispersion equations are included. The radial distribution can be overlooked when the ratio of column diameter is smaller than 1/10[13]. Particles and column diameters have been

chosen for this ratio as needed. In this case, the radial dispersion term of the equation was omitted and the differential equation for a packaged axial dispersion column was taken:

$D_{L} \frac{\delta^{2} C}{\delta X^{2}}-U \frac{\delta C}{\delta X}-\rho_{p} N_{A^{\prime}}=\varepsilon \frac{\delta C}{\delta t}$

The boundary and initial conditions are based on Danckwerts boundary conditions [16]. Therefore, for a Dirac delta function pulse input, boundary condition I is

At $\zeta=0, U M=U J(s)_{\zeta-0}-\left[\frac{D}{L} \frac{\delta J(S)}{\delta \zeta}\right]_{\zeta-0}$

and boundary condition II is

at $\zeta=1, \frac{\delta J(s)}{\delta \zeta}=0$

where $\mathrm{M}$ is the amount of tracer injected. For an inert tracer, [12].

$N_{A^{\prime}}=0$

Eq. (2) can be written in the Laplace domain as

$\frac{1}{P e} \frac{\delta^{2} J}{\delta \zeta^{2}}-\frac{\delta J}{\delta \zeta}-\frac{\varepsilon L}{U} \frac{\delta J}{\delta t}=0$

Eq. (6) can be solved in the Laplace domain for $\mathrm{J}=\mathrm{f}(\zeta, \mathrm{s})$. Then, using the relationship

$m_{n}=-1^{m} \lim _{s \rightarrow 0}\left(\frac{d^{n} \overline{C_{A}}}{d s^{n}}\right)$

theoretical moment expressions were obtained. For time zero, the first absolute moment and the second central moment for the column itself, the result is $[13,16,17]$.

$m_{0}=M$

$M_{1}=\frac{m_{1}}{m_{0}}=\frac{\varepsilon L}{U}$

and

$M_{2}^{M *}=\frac{M_{2}^{M}}{M_{0}^{M}}-\left[\frac{M_{1}^{M}}{M_{0}^{M}}\right]^{2}$

$M_{2}^{M *}=\frac{2}{P e}-\frac{2}{P e^{2}}\left[1-e^{-P e}\right]$

From observed response peaks, experimental values for time zero and for the first and second times can be obtained with the following equations,

$m_{0}^{E}=\int_{0}^{a} c d \tau \approx \sum_{i=1}^{n} C_{a v, i} \Delta \tau$

$m_{1}^{E}=\frac{\frac{1}{2} \sum_{i=1}^{n} C_{a v, i}\left(\tau_{i+1}+\tau\right)}{\sum_{i=1}^{n} C_{a v, i}}$

$m_{2}^{E}=\frac{\frac{1}{3} \sum_{i=1}^{n} C_{a v, i}\left[\tau_{i+1}^{2}+\tau_{i+1} \tau_{i}+\tau_{i}^{2}\right]}{\sum_{i=1}^{n} C_{a v, i}}$

The moments are calculated from zero to infinity. All moments must be determined to fully describe the distribution. Practically, these two are adequate for the characterization of residence time distribution 


\section{II.MATERIALS AND METHODS}

\section{A.MATERIALS}

The microbial lactase enzyme from Aspergillus oryzae (fungal lactase activity 100,000 U/g, ENZECO ${ }^{\circledR}$, Enzyme Development Corporation, New York) was used in this study. Duolite A568, a weak base ion exchange resin, was obtained from Rohm and Haas (USA). Lactose, glucose and galactose were reagent grade and purchased from Merck (Germany). Glucose detection kits were provided from LifeScan (LifeScan, Chesterbrook, Pennsylvania). $\mathrm{NaH}_{2} \mathrm{PO}_{4} \cdot 2 \mathrm{H}_{2} \mathrm{O}$ and $\mathrm{Na}_{2} \mathrm{HPO}_{4} \cdot \mathrm{H}_{2} \mathrm{O}$ were supplied from J.T.Baker (Holland) and used as phosphate buffer. Other chemicals were of analytical grade quality. The skim milk sample was obtained from a local market in Ankara.

\section{B. METHODS}

\section{B.1. Immobilization Of Enzyme Onto The Duolite}

Enzyme immobilization was achieved according to the method of adsorption [18]. The immobilized enzyme procedure was explained by Gürdaş et al. [8]. After the immobilization process, the particles were washed with distilled water to remove the free enzyme and used in this study [8].

\section{B.2. Experimental Set-Up}

The packed bed reactor used for the continuous experiment is shown in Figure 1. The reactor was linked to the substrate and product reservoirs. A peristaltic pump was supplied by the lactose solution to the column from the substrate reservoir.

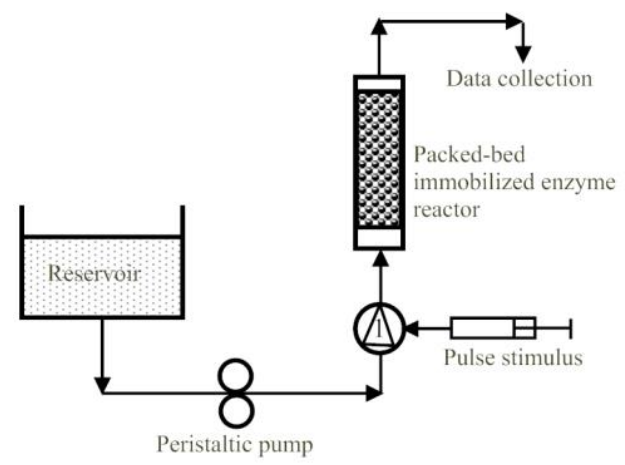

Figure 1. Schematic drawing of the packed-bed catalytic reactor

A packed bed reactor with an L/D [length $(8.93 \mathrm{~cm}) /$ diameter $(0.893 \mathrm{~cm})]$ ratio of 10 was filled with $1.55 \mathrm{~g}$ of Duolite A 568 resin (free base, FB) and average $390 \mu \mathrm{m}$ particle size. The system was washed with distilled water several times. Cylindrical Teflon columns (bed volume $=5 \mathrm{~mL}$ ) with different L/D ratios $(1,2,5$ and 10$)$ were used. The flow rate $(\mathrm{Q})$ of the substrate solution was changed in the range of $1-10 \mathrm{ml} / \mathrm{min}$. The void fraction of the bed $(\varepsilon)$ was 0.39 . The column was packed with $\beta$-galactosidase from Aspergillus oryzae immobilized on a weak base ion exchange resin.

\section{B.3. Stimulus-Response Experiments}

Stimulus-response experiments were conducted in three parts. Firstly, the dynamic behaviour of the column was investigated for the absence of diffusion and adsorption. For this purpose, the column was filled with Duolite A 568 resin and the system was then 'pulse' stimulated by adding $0.1 \mathrm{~mL}$ of cobalt (II) nitrate $\left(\mathrm{Co}\left(\mathrm{NO}_{3}\right)_{2} \cdot 6 \mathrm{H}_{2} \mathrm{O}\right)$ inert tracer to the eluate in order to determine the reference response of 
the column. Secondly, the diffusion behaviour under conditions of no adsorption was investigated, the column was filled with Duolite A 568 resin and then 'pulse' stimulated by adding $0.1 \mathrm{~mL}$ of $4 \mathrm{M}$ cobalt (II) nitrate inert tracer. The column response, which is the so-called ' $\mathrm{C}$ curve', was determined by following the concentration of inert tracer. In each case, absorbance at $510 \mathrm{~nm}$ of the tracer concentration solution was measured with a spectrophotometer (Shimadzu 1201 PC, Shimadzu Corporation, Kyoto, Japan).

In the late parts of the study, the column was filled with $\beta$-galactosidase immobilized on Duolite A 568 resin and then the system was 'pulse' stimulated with the addition of $125 \mathrm{mM}$ lactose solution $(4.5 \%)$. All the experiments were carried out at room temperature $\left(20{ }^{\circ} \mathrm{C}\right.$, max. deviation $\left.\pm 2{ }^{\circ} \mathrm{C}\right)$. The column response was determined by measuring the glucose concentration in the eluent stream using a glucose detection kit.

\section{B.4. The Performance Of Immobilized Enzyme}

The enzyme immobilized on Duolite A568 particles was tested for industrial applicability. Therefore, a packed bed reactor with different L/D ratios (1,2, 5 and 10) was filled with enzyme-immobilized particles. A 4.5 percent lactose solution $(125 \mathrm{mM})$ was constantly fed into the packed bed reactor through a single pass (without recycling). The flow rate of the lactose solution was $1-10 \mathrm{~mL} / \mathrm{min}$, and the total reaction time was 480 minutes. At the end of each cycle of the enzymatic reaction, 500 microliters of the reaction mixture (not the complete final product) were taken from the packed bed reactor and its glucose content was determined using a glucose assay kit [8]. In the late parts of the study, a packed bed reactor with an L/D [length $(8.93 \mathrm{~cm}) /$ diameter $(0.893 \mathrm{~cm})$ ] ratio of 10 was filled with $1.55 \mathrm{~g}$ of enzyme immobilized particles. The flow rate of the substrate was $4 \mathrm{~mL} / \mathrm{min}$. A skim milk sample four times greater than the column volume was passed through the system. Ten samples were collected every 10 seconds and the amount of glucose, which is one product of the reaction, was measured. The average of the measurements was taken and the rate of the conversion of lactose into glucose was measured.

\section{RESULTS AND DISCUSSION}

In this study, the parameters of the column (L/D ratio and solution flow rate) that influence the working performances of packed bed column reactors were studied. The determined parameters were investigated by a stimulus-response technique; an impulse type stimulation was given at the inlet of the column and the reply curves at the outlet were calculated. Evaluating the response curves, Peclet number, axial dispersion coefficient, conversion and Damkohler number, reaction rate constants have been calculated.

In this part of the study, the influences of the column L/D ratio and flow rate on the Peclet number were investigated. An inert cobalt solution was added to the system as an impulse type stimulation and response curves were determined at the outlet of the column. The absolute moments and central moments of the response curves were evaluated and Peclet numbers were calculated with the help of Eq (11).

Peclet number:

$P e_{L}=\frac{U_{L}}{D_{L}} \quad$ or $\quad P e_{p}=\frac{U D_{P}}{D_{L}}$

stating the proportion of bulk mass transfer to axial dispersion coefficient. It can be defined according to the column length $\left(\mathrm{Pe}_{\mathrm{L}}\right)$ or particle diameter $\left(\mathrm{Pe}_{\mathrm{P}}\right)$. If the $\mathrm{Pe}$ number is high, that is, the axial dispersion coefficient is low, it shows that we have approached plug flow (PF); however, if the Pe coefficient is low, it shows that we have approached the conditions in a continuous stirred tank reactor (CSTR) because the axial dispersion coefficient is high [12]. Peclet numbers calculated with the help of Eq (11) and their change with the ratio of column L/D are shown in Fig $2 \mathrm{a}$. 
As can be understood from the figure showing the influence of flow rate on Peclet numbers, with a rising flow rate the Peclet number decreases in the beginning but then achieves a balance approaching a plateau value. The same flow behaviour was observed for different L/D ratios. This situation shows that the behaviour of the flow changes from plug flow to CSTR just as expected. With the rise in column L/D ratio, smaller Peclet number values were obtained. It was also noted that the flow shape couldn't be precisely formed because of the decrease in L/D ratio.

The axial dispersion coefficient was calculated using equation 15 . The change is the calculated axial dispersion coefficient with the flow rate and column L/D ratio is given in Fig 2 b.

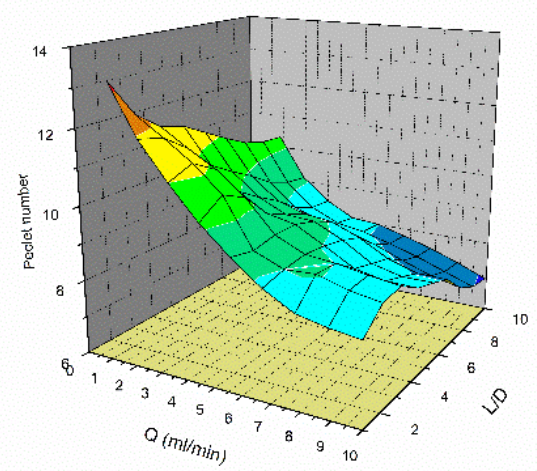

Figure 2a. Effects of flow rate $(Q)$ and length/diameter $(L / D)$ ratio on peclet number $(P e)$.

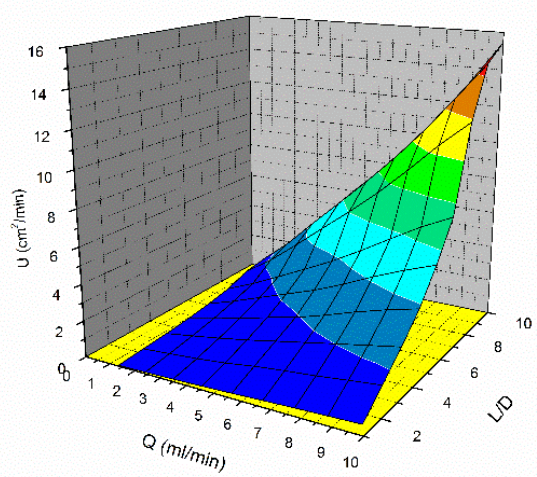

Figure $2 \boldsymbol{b}$. Effects of flow rate $(Q)$ and length/diameter $(L / D)$ ratio on axial dispersion coefficient $(U)$.

The axial dispersion coefficient also increased in parallel with the rise in flow rate. When Peclet numbers and axial dispersion coefficients are taken into consideration together, the column dynamics can be better explained. The Peclet number deceaseses at first with the rise in flow rate; however, it is then not affected any further. The rise in the flow rate in the portion where the Peclet number is constant, that is to say the mass transfer increased, led to the rise in the axial dispersion coefficient.

The rise in the axial dispersion coefficient shows that the flow in the column approached CSTR. The presence of an effective mixture is among the methods used to increase the output of a reaction in systems where there is mass transfer resistance [15]. The axial dispersion coefficient is quite important parameter in preparing a packed bed column reactor. When choosing the parameters used in a packed bed column system, attention must be paid to the fact that axial dispersion coefficients are high. However, expressions of enzymatic reaction speed must also be taken into consideration. With a rise in the column L/D ratio, the axial dispersion coefficient also increased. The fact that interstitial velocity is higher in the reactor which has the larger L/D ratio under the same flow ratio also led to the rise in the axial dispersion coefficient. 
The influence on enzymatic conversion of the flow rate and column L/D ratio in packed bed column reactors was investigated by analyzing Damkohler numbers and reaction rate constants. For this purpose, using the optimum immobilized parameters determined before, the enzyme was immobilized [8] and put on four columns with different L/D ratios. The study was carried out with a single pass system and used the data gathered for enzymatic conversion at different flow rates; Damkohler numbers and reaction rate constant values were determined and the results were given by the figures.

An increase in the flow rate negatively affects the conversion in a single pass system. This occurs because of the increase in the flow rate and the decrease in residence time. In order to see the influence of flow rate on enzymatic conversion, conversion was divided into residence times and then the values of the conversion rate were calculated. The effect of the flow rate and column L/D ratio on conversion rate can be seen in Fig 3 .

The increase in the flow rate caused a rise in conversion rate. The value of this rise decreased at higher flow rates and approached the conversion rate plateau value. It is known that with a rise in flow rate, mass transfer resistances on the surfaces of the particles decrease and the enzyme substrate interaction outlet increases [19]. The increase in the rate of conversion rise to the minimum level where mass transfer resistances could reach and this value approached a constant value.

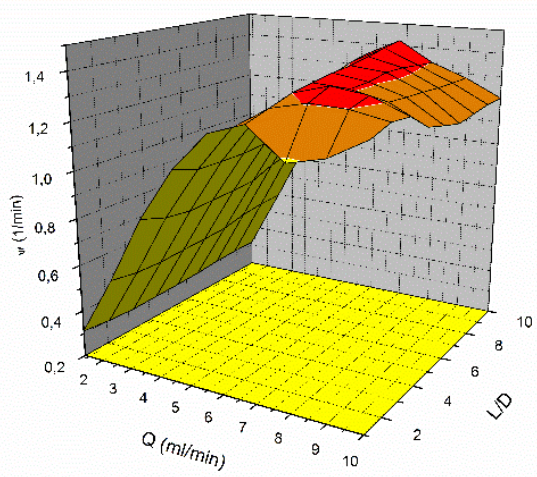

Figure 3. Effects of flow rate $(Q)$ and length/diameter $(L / D)$ ratio on conversion rate $(\Psi)$.

It can be seen that the rate of conversion in terms of unit residence time decreased as the flow rate increased. At lower rates, the resistance of the film layer surrounding the particles reduced the enzymatic reaction rates. When high feed flow rates were reached, a decrease in reaction rate was seen since the resistance time was greatly decreased. This situation is more clearly seen in the column whose L/D ratio is 10 .

As can be seen in the figures, conversion increased with a rise in the flow rate and then conversion decreased (fig 4). At low flow rates, conversion values decreased because of film resistance and at the high rates they decreased due to decreasing residence time. At low rates, because of film resistance, the substrate and catalyzator couldn't interact sufficiently. In order to maintain the film resistors at the lowest level with the aim of reaching high values of conversion, one must study the system at high rates, but for this system the value of $4 \mathrm{~mL} / \mathrm{min}$ mustn't be exceeded. 


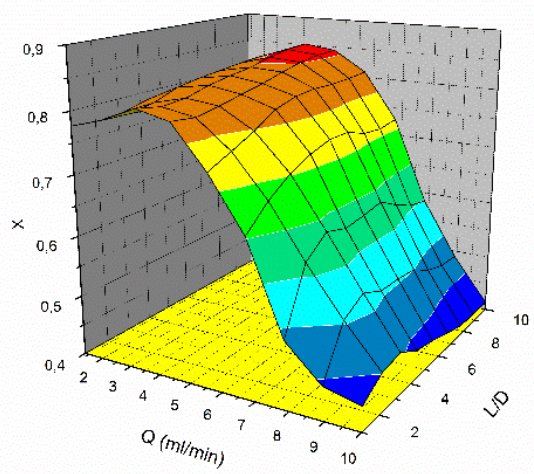

Figure 4. Effects of flow rate $(Q)$ and length/diameter $(L / D)$ ratio on conversion $(X)$.

In the previous results, it was declared that the columns that had higher L/D ratios had higher axial dispersion coefficients. This effect continues until the enzymatic reaction rate becomes limiting. The Damkohler number:

$D a=\frac{-r_{S_{0}} V}{F_{S_{0}}}=\frac{k C_{S_{0}} V}{u_{0} C_{S_{0}}}$

is defined as the ratio of the maximum reaction rate to the maximum transfer rate. When Damkohler number is less than 1 , it shows that the maximum mass transfer rate is larger than the maximum reaction rate (low mass transfer rate) and the limiting factor in the system is the enzymatic reaction. However, if the Damkohler number is greater than 1, it shows that the substrate that is necessary for the reaction cannot reach the enzyme sufficiently well due to high mass transfer rates, and the limiting factor is the mass transfer rate. As can be seen, the Damkohler number provides a great deal of information about the reaction system.

In this part of the study, the effects of column L/D ratio and flow rate on the Damkohler number were studied. For this reason, Danckwerts equation, which was developed for first order reactions, was used. It is known that Michailes-Menten equations approach the kinetics of first order reactions at low substrate concentrations [13]. In this study it has been studied at concentrations $\mathrm{K}_{\mathrm{m}}$ and the enzyme kinetics were regarded to be first order. Danckwerts equation:

$X=1-\frac{4 q \exp \left({ }^{P E_{L}} / 2\right)}{(1+q)^{2} \exp \left[\frac{P e_{L} q}{2}\right]-(1-q)^{2} \exp \left[-\frac{P e_{L} q}{2}\right]}$

$q=\sqrt{1+\frac{4 D a}{P e_{L}}}$

The Damkohler number was calculated using the Peclet numbers and conversion values that were determined previously in Eq. (17) and Eq. (18). The effects of column L/D ratio and flow rate on the Damkohler number are shown in Fig 5. With the rise in the flow rate, the Damkohler (Da) number decreases and at the higher flow rates the increase slows down. The fact that the flow rate increases in the area where the Da number is large shows that the increase in the maximum reaction rate is larger than that of the mass transfer rate. It is an expected situation that the mass transfer resistances decreases with the rise in the flow rate. Because of this, more substrate is able to reach the enzyme and react. This situation expresses that the rate limiting step for the enzymatic reaction is the mass transfer rate. 


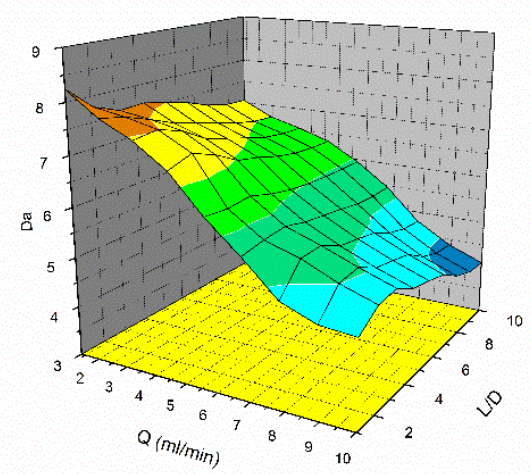

Figure 5. Effects of flow rate $(Q)$ and length/diameter $(L / D)$ ratio on Damkohler number $(D a)$.

At the high flow rates, more substrate reaches the enzyme; however, since enzyme in limited quantity cannot influence each other with substrate more than it can catalyze, the limiting factor is the amount of enzyme (activity). For this reason, though the maximum transfer rate increases, the Da number decreases at high flow rates because the maximum reaction rate stays constant.

With the rise in the column L/D ratio, the Da number increased as seen in the figures. Previous results have shown that columns with high L/D ratios have low Peclet numbers and higher axial dispersion coefficients, and thus have higher mass transfer rates. The fact that the L/D ratio in the fixed-bed reactors is high causes the enzymatic reaction rate to be higher, and this situation give rise to the increase in the Da number.

With the aim of the effects of determining Damkohler number and column L/D ratio on conversion, Da number against conversion and column L/D turned into graphic and is shown in Fig 6 .

The Damkohler number for first order reactions is defined as:

$D a=T \times k$

Here $\tau$ shows residence time ( $\min )$ and $\mathrm{k}$ is reaction rate constant $\left(\mathrm{min}^{-1}\right)$. As shown in the equation, Da number can be increased in two ways. These are by increasing the residence time and the reaction rate constant. As increasing flow rate leads to a decrease in the residence time, Da number is negatively affected. On the other hand, as the rise in flow rate increases the mass transfer rate, the reaction rate constant and thus the Da number increase. For this reason, optimization of the flow rate gains importance.

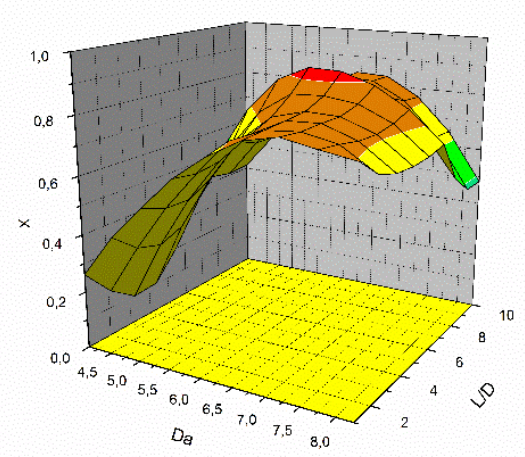

Figure 6. Effects of Damkohler number (Da) and length/diameter (L/D) ratio on conversion $(X)$. 
At flow rates with high Dankohler numbers, this is more clearly seen when the flow rate-Da number (fig 5) and the Da number-conversion graphic (fig 6) are investigated together, that conversion rate is also high. This flow rate changes in the range of $1-10 \mathrm{~mL} / \mathrm{min}$, depending on the column L/D ratio. In accordance with the previous results, it was found that the fact that increases in the column L/D ratio positively affect the conversion rate and Da number.

With the aim of determining the effect of column L/D ratio on the reaction speed constant, the reaction rate constant was calculated using Eq. (19). The reaction kinetics, as expressed before, were regarded as of the first order as studied at concentration $\mathrm{K}_{\mathrm{m}}$. The effects of flow rate and column L/D ratio on reaction rate constants are given in Fig 7.

Though the reaction rate constant rapidly increased up to $6 \mathrm{~mL} / \mathrm{min}$ with the rising flow rate, the amount of the increase then slowed and approached a plateau value. Despite very little increase in the flow rate constant with coming up this flow rate, as the residence time decreases the Da number also decreases. Thus, lower conversion values were obtained. As the column L/D ratio increased, the reaction rate also increased. These results are in accord with the conversion rate and Da number results.

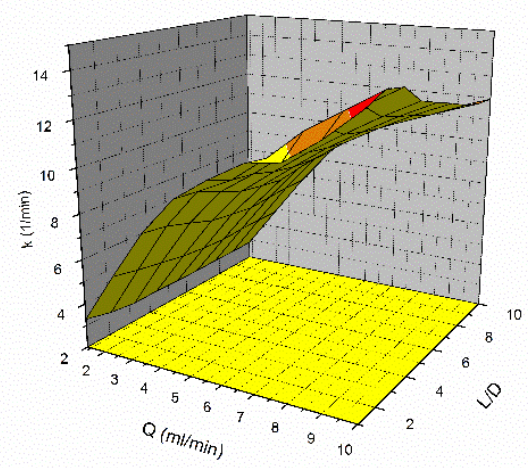

Figure 7. Effects of flow rate $(Q)$ and length/diameter $(L / D)$ ratio on reaction rate constant $(k)$.

The influence of flow rate and L/D ratio on the conversion was also investigated. Conversion increased with rising flow rate, and then decreased. At low flow rates, conversion values decreased because of film resistors, while at high rates the values decreased due to the decreasing residence time. Because of film resistors at low rates, substrate and catalyst couldn't interact sufficiently. In order to maintain the film resistors at the lowest level to reach high values of conversion, the study must be conducted at high rates, but in this system a value of $4 \mathrm{ml} / \mathrm{min}$ must not be exceeded.

It was found that the fact that increases in the column L/D ratio positively affects conversion. The highest conversion was obtained at an L/D ratio of 10 , out of four different column L/D ratios. Better axial dispersion was provided with increased column length and decreased column diameter, and the residence time was found to be longer compared to other columns.

\section{A. THE PERFORMANCE OF IMMOBILIZED ENZYME}

For the immobilized enzyme reactor's efficiency, lactose conversion was utilized as a criterion. Lactose hydrolysis by immobilized $\beta$-galactosidases was performed in a packed bed reactor, as previously mentioned. The immobilized enzyme's properties for lactose hydrolysis of buffered lactose solutions $(4.5 \% \mathrm{w} / \mathrm{v})$ were investigated. There are several studies in the literature related to lactose hydrolysis in batch and continuous systems via soluble. $\beta$-galactosidase from Kluyveromyces lactis onto a graphite surface via cross-linking and reported that the lactose conversion was found to be $70 \%$ at $37{ }^{\circ} \mathrm{C}$ within $3 \mathrm{~h}$ in batch systems [20]. In other studies, at a residence time of $11.8 \mathrm{~min}, 30.23 \%$ of lactose was 
hydrolysed after passing through the enzymatic reactor in a recycling continuous system. When the residence time was increased to $43.7 \mathrm{~min}$, the lactose conversion doubled $(64.76 \%)$ [21]. In this study, at a residence time of $0.91 \mathrm{~min}, 55 \%$ of the lactose was hydrolysed by the immobilized enzyme reactor in a single pass continuous system. This result compares with similar studies in the literature where greater conversion with minimal residence time was achieved.

\section{CONCLUSION}

The parameters of column L/D ratio and solution flow rate which influence the working performances of packed bed column reactors have been studied. The determined parameters have been investigated by a stimulus-response technique. An impulse type stimulation was given at the inlet of the column, the response curves at the outlet were drawn and the collected data were studied using the moment technique. Evaluating the response curves, Peclet numbers, axial dispersion coefficients, conversion ratios, Damkohler numbers, and reaction rate constants were calculated.

When the results of this study are evaluated, it can be seen that in order to obtain a high level of conversion within a unit residence time in a packed bed column reactor prepared with Duolite A568 resin on which $\beta$-galactosidase enzyme was immobilized, columns with low particle diameters (390 $\mu \mathrm{m})$ and high L/D ratios (L/D:10) should be preferred.

In order to obtain high conversion in unit residence time, the enzyme was immobilized to the resin using optimal immobilization parameters and the enzyme immobilized packed bed column was prepared by filling a column with an L/D ratio of 10 with the enzyme immobilized particles. The flow rate was set at $4 \mathrm{~mL} / \mathrm{min}$ and instead of lactose solution $(4.5 \% \mathrm{w} / \mathrm{v})$, milk was passed through the system. It was determined that the enzyme immobilized packed bed reactor hydrolysed the lactose in the milk at the rate of $55 \%$ with a residence time of $0.91 \mathrm{~min}$. It was seen that the enzyme immobilized packed bed column provided the expected conversion in a single pass continuous system and thus the aim of the study was achieved. Once the results are evaluated, it is believed that this study will provide important advantages in industrial applications

ACKNOWLEDGEMENTS: Financial support from CUBAP (project no. M-343) is gratefully acknowledged.

\section{V.REFERENCES}

[1] M. Messia, T. Candigliota, E. Marconi, "Assessment of quality and technological characterization of lactose-hydrolyzed milk," Food Chemistry, vol. 104, no.3, pp. 910-917, 2007.

[2] E. Jurado, F. Camacho, G. Luzon, J. Vicaria, "A new kinetic model proposed for enzymatic hydrolysis of lactose by a $\beta$-galactosidase from Kluyveromyces fragilis," Enzyme and Microbial Technology, vol. 31, no.3, pp. 300-309, 2002.

[3] R. Panesar, P.S. Panesar, R.S. Singh, M.B. Bera, "Applicability Of Alginate Entrapped Yeast Cells For The Production Of Lactose-Hydrolyzed Milk," Journal of Food Process Engineering, vol.30, no.4, pp. 472-484, 2007.

[4] E. Sharp, N.M. D'Cunha, C. S. Ranadheera, T. Vasiljevic, D.B. Panagiotakos, N. Naumovski, "Effects of lactose-free and low-lactose dairy on symptoms of gastrointestinal health: A systematic," International Dairy Journal, vol.114, 104936, 2021. 
[5] D.G. Hatzinikolaou, E. Katsifas, D. Mamma, A.D. Karagouni, P. Christakopoulos, D. Kekos, "Modeling of the simultaneous hydrolysis-ultrafiltration of whey permeate by a thermostable $\beta$-galactosidase from Aspergillus niger," Biochemical Engineering Journal, vol.24, no. 2, pp.161-172, 2005.

[6] M. Ladero, A. Santos, F. Garcia-Ochoa, "Diffusion and chemical reaction rates with nonuniform enzyme distribution: An experimental approach," Biotechnology and Bioengineering, vol.72, no.4, pp.458-467, 2001.

[7] I. Roy, M.N. Gupta, "Lactose hydrolysis by Lactozym"M immobilized on cellulose beads in batch and fluidized bed modes," Process Biochemistry, vol.39, no.3, pp. 325-332, 2003.

[8] S. Gürdaş, H.A. Güleç, M. Mutlu, "Immobilization of Aspergillus oryzae $\beta$-galactosidase onto Duolite A568 resin via simple adsorption mechanism," Food and Bioprocess Technology, vol.5, no.3, pp. 904911, 2012.

[9] D. Nemec, J. Levec, "Flow through packed bed reactors: 1. Single-phase flow," Chemical Engineering Science, vol.60, no.24, pp. 6947-6957, 2005.

[10] D. S. Wentworth, D. Skonberg, D.W. Donahue, A. Ghanem, "Application of chitosan-entrapped $\beta$ galactosidase in a packed-bed reactor system," Journal of Applied Polymer Science, vol.91, no.2, pp. 1294-1299, 2004.

[11] V.V. Kafarov, "Cybernetic methods in chemistry \& Chemical engineering”, Moscow, Mir Publishers, 1976.

[12] O. Levenspiel, "Chemical reaction engineering," Industrial \& Engineering Chemistry Research, vol.38, no.11, pp. 4140-4143, 1999.

[13] Mutlu, M., Sağ, Y., Kutsal, T., "The adsorption of copper (II) by Z. ramigera immobilized on Caalginate in packed bed columns: a dynamic approach by stimulus-response technique and evaluation of adsorption data by moment analysis," The Chemical Engineering Journal and The Biochemical Engineering Journal, vol.65, no.1, pp.81-86, 1997.

[14] J.M. Smith, “Chemical engineering kinetics”, 2nd ed., USA, McGraw-Hill Inc, 1981.

[15] I.H. Boyaci, "Dolgulu Kolon Entegre Edilmiş Enzim Elektrot Sistemleri ile Gıda Örneklerinde Glukoz, Sukroz ve Laktoz Miktarının Saptanması," Doktora tezi, Gıda Mühendisliği Bölümü, Hacettepe Üniversitesi, Ankara, Türkiye, 2001.

[16] E.E. Petersen, “Chemical reaction analysis”, Prentice Hall, 1965.

[17] M. Mutlu, E. Piskin, "Blood plasma proteins on polyurethane and alkylsiloxane plasma-treated polyurethane surfaces. Dynamic approach by stimulus-response technique", Medical and Biological Engineering and Computing, vol.28, no.3, pp. 232-236, 1990. 
[18] S. Gürdas, H.A. Güleç, M. Mutlu, "Adsorption Isotherm and Kinetic Modelling of [beta]-Galactosidase Immobilization onto a Basic Resin (Duolite A568)," Asian Journal of Chemistry vol.23, no.3, pp.1049, 2011

[19] Y. Cho, J. Bailey, "Immobilization of enzymes on activated carbon: properties of immobilized glucoamylase, glucose oxidase, and gluconolactonase," Biotechnology and Bioengineering, vol.20, no.10, pp. 1651-1665, 1978.

[20] Q.Z. Zhou, X.D. Chen, "Immobilization of $\beta$-galactosidase on graphite surface by glutaraldehyde," Journal of Food Engineering vol.48, no.1, pp. 69-74, 2001.

[21] X. Li, Q.Z. Zhou, X.D. Chen, "Pilot-scale lactose hydrolysis using $\beta$-galactosidase immobilized on cotton fabric," Chemical Engineering and Processing: Process Intensification, vol.46, no.5, pp.497500, 2007. 